\title{
Teacher Participation Styles in Foreign Language Chats and Their Effect on Student Behavior
}

\author{
Estela ENe \\ SENTA E. Görtler \\ KARA MCBRIDE \\ University of Arizona, Tucson
}

\section{ABSTRACT}

This paper investigates the impact that a teacher's virtual presence-or lack thereof-has on students' chat behavior with regard to error correction, uptake, target language use, and on-task behavior. The data come from beginning German students engaged in pair and small-group chatting activities at a major American university. Transcripts from chat sessions in a first-semester German class and a second-semester German class were analyzed. The data were triangulated with student surveys and teacher interviews. Results suggest that the teachers' participation styles had a greater influence on learners' chat behavior than simply whether or not the teachers were present and that the form-focused participation style of one of the teachers had an apparently inhibitory effect on learner participation.

\section{KEYWORDS}

Chat, Learner Behavior, German, Teacher Effect, Error Correction

\section{INTRODUCTION}

To date, computer-mediated communication (CMC) research has focused on student participation patterns and their effects on second/foreign language acquisition. Teachers' roles, on the other hand, have not received as much attention in $\mathrm{CMC}$ studies. The present article aims to fill this gap in the research by investigating teachers' roles in synchronous $\mathrm{CMC}$ and by determining the importance of teachers' presence in a first- and second-semester foreign language classroom chat. In particular, we investigate the differences between teachers' chat room participation styles and their effect on the learners' opportunities for language acquisition. Input, output, error correction, and uptake-all assumed to enhance language acquisition - were the means of determining the impact of teachers' participation styles on learners' experience. 


\section{LITERATURE REVIEW}

Interaction between learners as well as between learners and language teachers, native speakers (NSs), or more advanced learners can enhance second language acquisition (SLA) (Long, 1996). As pointed out by Gass and Selinker (2001), output embedded in interaction plays several roles in SLA: (a) it helps learners create knowledge through syntactic and semantic processing (Swain, 1985), (b) it allows learners to practice or apply existing knowledge, (c) it fosters automaticity, (d) it provides an opportunity to elicit further input, and (e) it offers the opportunity to test hypotheses and to receive feedback about previously formed target language (TL) hypotheses. Other researchers such as Swain and Lapkin (1995) and Izumi, Bigelow, Fujimara, and Fearnow (1999) have also confirmed the important role of output in SLA.

Within the interactionist framework, feedback that is embedded in interaction is claimed to facilitate SLA. A modification of the learner's TL grammar can be triggered by several factors such as attending to input (especially modified input such as foreigner talk), noticing differences between hypotheses formed and actual NS production, testing hypotheses during output, and receiving implicit and explicit feedback in response to language production. Within this framework, negative evidence provided during interaction is crucial. Long (1996) argued that "negative feedback obtained in negotiation work or elsewhere may be facilitative of SL development at least for vocabulary, morphology, and language-specific syntax, and essential for learning certain specifiable L1-L2 contrasts" (p. 414).

The focus of much discussion in SLA has been whether to provide corrective feedback explicitly or implicitly. Explicit negative feedback includes overt error correction (i.e., the correction is clearly identifiable, and a correct form is supplied) or rule explanation. Overt, or explicit, error correction, "provides explicit signals to the students that there is an error in the previous utterance" (Panova \& Lyster, 2002, p. 584). Implicit negative feedback includes recasts (simple and complex), as well as negotiation moves following a communication breakdown such as confirmation checks, clarification requests, and repetitions (Long \& Robinson, 1998).

While explicit negative feedback clearly interrupts the flow of the conversation, implicit negative feedback is less disruptive. Within the perspective of implicit negative feedback, Lyster and Ranta (1997) found recasts to be the most frequent form of implicit correction. Nicholas, Lightbown, and Spada (2001) summarized the essential features of recasts as acknowledging content, providing positive affect, and modeling the correct form. Recasts also provide positive evidence for the reformulation and are claimed to promote noticing by contrasting learners' ill-formed utterance to the teacher's reformulated TL utterance (Saxton, 1997). Recasts can be accompanied by overt signals (e.g., tone of voice and facial expression in face-to-face interaction). When this happens, the combination of overt signals and recasts could arguably be construed as explicit negative feedback (Nicholas et al., 2001). Although there is evidence to suggest that both implicit and explicit forms of corrective feedback can help learners produce more accurate utterances (Carroll \& Swain, 1993), recasts result in student self-correction less 
often than more explicit forms, such as metalinguistic feedback (Lyster \& Ranta, 1997).

When looking at corrective feedback, one also has to consider what happens after the correction. One possible reaction, if not the desired reaction, to corrective feedback is uptake. Panova and Lyster (2002) defined uptake as “ ... different types of student responses immediately following the feedback, including responses with repair of the nontarget items as well as utterances still in need of repair" (p. 574). Lyster and Ranta (1997) also differentiated between two different forms of uptake: uptake with repair and uptake that needs repair. By their definition, acknowledgment of the corrective feedback, repetition by the learner, and self-repair should all be considered uptake. Mackey and Philp (1998) argued against this narrow definition, suggesting that uptake often does not occur until later in the conversation. The use of uptake as a measure of noticing and as a measure of SLA has not been without controversy, as evidenced even in the various ways the concept has been defined. In a more conversational learning environment, the context of the discourse may make it seem awkward to repeat the utterance (Lyster, 1998; Oliver, 1995, 2000) although the correction may have been noticed.

While many studies have investigated corrective feedback types and their effectiveness for language learning in traditional classroom and natural learning environments, to our knowledge there are no published studies that substantially focus on error correction in a CMC environment. CMC is one way that foreign language (FL) teachers strive to maximize classroom time in which students have the opportunity to use the TL and negotiate meaning. Numerous reasons for using synchronous CMC (i.e., chat) in the FL classroom have been cited. Early studies found that CMC: (a) increases language production (Beauvois, 1992, 1998a; Kern, 1995), (b) encourages TL use (Beauvois, 1992, 1997, 1998a; Chun, 1994; Kelm, 1992), (c) decreases teacher dominance (Beauvois, 1998a; Kern, 1995), (d) provides a voice to those who do not have one (Batson, 1988) and equalizes participation especially for shyer and minority students (Beauvois, 1992, 1998a; Bump, 1990; Kelm, 1992; Kern, 1995; Warschauer, 1996), (e) increases students' willingness to discuss topics openly and honestly (Beauvois, 1992, 1998a), (f) increases student motivation (Batson, 1988; Beauvois, 1992; Bump, 1990; Kelm, 1992), (g) decreases anxiety (Beauvois, 1992, 1998a), (h) improves reading comprehension (Kelm, 1992), (i) improves writing ability (Chun, 1994), and (j) can generally benefit language development (Beauvois, 1992; Chun, 1994; Kelm, 1992; Kern, 1995; Warchauer, 1996). The medium-specific features of CMC (e.g., slower speed, editing capabilities, and option to re-read messages) were listed as possible explanations for such benefits.

However, Kelm (1992) voiced caution in regard to the transferability of skills from written CMC communication to oral communication. More recent studies have argued that synchronous $\mathrm{CMC}$ has no negative effect on the development of oral proficiency (Kost, 2004) and might even be beneficial (Beauvois, 1998b; Payne \& Whitney, 2002). Others have expressed concerns with respect to the complexity of the language produced (Chun, 1994) and the accuracy of postings 
in CMC (Beauvois, 1992; Kern, 1995), while yet others have feared that, because CMC is written, peer errors would result in increased error uptake (Kelm, 1992). Indeed, there is evidence that, when chatting, students sometimes integrate other students' errors into their own interlanguage (Beauvois, 1992; Kelm, 1992; Storch, 2002) and that learners tend to pay less attention to accuracy (Beauvois, 1992; Kelm, 1992).

A teacher's intervention might help mitigate some of these concerns, which, after all, are not unique to CMC environments. The ways in which a teacher can intervene in student-to-student interactions is different in chat than in classroom activities. The teacher does not need to physically go from group to group but can, instead, drop in on a conversation at the push of a button. In addition, the way in which the teacher's presence then becomes known to students in chat sessions differs. In some chat programs, the teacher's arrival is announced with a line of text; in others, the teacher's presence is announced only when the teacher makes a contribution to the chat. In either case, it might be that the teacher's presence is perceived as less intrusive by students than when the teacher is physically present in traditional group discussions. (Sometimes, however, the teacher is seen as an intruder in CMC [Donaldson \& Kötter, 1999; Kötter, 2003]). The question still remains as to which particular interaction style of the teacher in which particular CMC situation is seen as less intrusive.

Lynch (1997), in comparing different teachers' roles in intermediate adult English as a foreign language (EFL) conversations during group work, found that too much or too little assistance on the part of the teacher resulted in stifling students' participation. The best kind of intervention, he concluded, encourages negotiation that is already under way, as opposed to trying to initiate it. Walsh (2002) in a case study of eight experienced EFL teachers reached similar conclusions, urging limited teacher intervention with minimal error correction and withdrawal from participation once the conversation has gotten underway. Panova and Lyster (2002) found that feedback types that elicit information from learners result in more error repair than less engaging forms of feedback. These studies, however, were conducted in traditional classrooms and included no CMC. Because the nature of the teacher's role in a chat session is different from that in a traditional classroom setting, there is a need to investigate what kind of teacher behavior in FL chat rooms either encourages or discourages student participation and negotiation of meaning.

Perhaps the most dramatic difference between classroom environments and $\mathrm{CMC}$ environments lies in the way turn taking is managed. In comparison to oral forms of communication, participants can be ignored in chat sessions, making management of turn taking easier in some regards (Kern, 1995). This situation can lead to chaos (Bump, 1990; Kern, 1995) but can be controlled by maintaining smaller group sizes. (Beauvois, 1992 suggested small conferences; Böhlke, 2003; Bump, 1990 suggested a limit of four or five participants.)

Both teachers and students can introduce new topics in the chat environment (Beauvois, 1998a; see also Gonzalez-Bueno, 1998). As the students take more control of the course of the conversation, the greater the possibility of the conver- 
sation going off task. Going off task may or may not be seen in a negative light since off-task turns could produce quality language. All of this may be related to the fact that, as Kern (1998) notes, "the teacher has no mechanism by which to allocate the floor, which is equally available to all group members at all times. As a consequence, many student comments surface that might never be heard in a normal classroom discussion" (p. 62). Finally, in computer lab environments, because of the diminished eye contact between chat participants and the teacher and their attention focused on the computer rather than the teacher at the front of the room, there is less of a tendency for students to direct comments to the teacher rather than to the group as a whole.

There are other ways in which the teacher's presence could be perceived as less of an interruption, particularly in error correction. The chat system's capacity to allow two participants to work simultaneously on their contributions without interrupting each other's turns encourages increased production in chat exchanges with students. In this kind of system, the fact that the teacher's error corrections would never actually cut off a student's turn mid-sentence (but could be reviewed later in the conversation by scrolling back to the teacher's comment) might prove to be a substantial benefit of chatting.

In sum, because the nature of the teacher's roles in chat sessions is different from that in a traditional classroom setting, there is a need to investigate the relationship between the teacher's behavior and students' interactions in FL chat rooms. In the conventional classroom, the teacher normally controls the floor and the topic of conversation. However, in chat sessions, the teacher is less dominant, which may lead to more student participation and also more off-task behavior. On the other hand, the students may feel more accountable for their language production due to the fact that it is recorded and thus subject to teacher (and peer) review. This accountability may result in more on-task behavior and TL use. The changed dynamic of the conversation may cause students to ignore error correction, or it may facilitate more noticing of feedback because the flow of conversation is not interrupted. Finally, reduced teacher dominance in students' interactions may encourage more peer feedback.

\section{RESEARCH QUESTIONS}

This study examines the effect of a teacher's presence in chat rooms by investigating the following research questions:

1. How are TL use, error correction, and on-/off-task behavior affected by the teacher's presence and actions in a chat room in which beginning FL learners are interacting to complete a task?

2. What are the students' perceptions about the teacher's role in and effect on chat room interactions?

3. How do these perceptions compare with observed effects of the teacher's presence in the chat room?

The first research question will be answered with the help of an analysis of the chat transcripts from two first-year German classes. Chat transcripts from two 
classes were separated into categories characterized by the teacher's presence or absence. TL use and on-/off-task behavior were determined based on the number of turns produced in the TL and the number of turns produced in on-/off-task posts. Error correction was measured by the teacher's corrective feedback moves in response to students' errors; the effectiveness of the teacher's corrective feedback was measured by the degree of students' uptake. Students' perception of the teacher's role were elicited in a student survey administered at the end of the semester. The results from the survey were triangulated with the results from the chat transcript and analysis of interviews with the two teachers involved in the project.

\section{RESEARCH DESIGN}

\section{Setting and Participants}

The research was conducted at the University of Arizona in Tucson. The participants were recruited from a first- and a second-semester German class that engaged in weekly chatting activities. The classes were taught by two female teachers. The first-semester teacher was also one of the researchers. Both instructors were experienced Graduate Teaching Assistants/Associates who had been using chat in their FL courses for more than 2 years.

\section{First-semester Class}

The composition of the first-semester class was rather unusual. It was dominated by nontraditional learners (i.e., graduate and undergraduate students proficient in other languages and a high school student). Fourteen students were enrolled in the class, including six nonnative speakers of English (four Spanish speakers and two Norwegian speakers). All students used English in their normal everyday interactions. The ages of the students ranged from 16 to 35 years of age. The students did not express or otherwise display anxiety about typing or using a computer in general, and the instructor did not perceive any resistance to working with computers.

The students engaged in chat interactions for 10 to 20 minutes at the end of class once a week, and the chat activities were either information-gap or role-play activities (see sample activity in Appendix A). Students chatted in pairs or groups of three, following grouping practices of the traditional classroom. The students and the teacher were present in the computer lab at the same time. Although the students were not supposed to talk to each other in person, they sometimes did. Some students also availed themselves of online dictionaries while chatting.

The teacher of the first-semester class used a chat program produced by the College of Humanities at the University of Arizona. The participants saw their own chat room on their screen. Each computer was used by one participant only, and the total number of chat rooms varied between five and seven. The chat room software contained a large window for the discussion at hand, a small window listing the participants in the given chat room, and a bar displaying German characters with diacritics (see Figure 1). 
Figure 1

College of Humanities University of Arizona Chat Program

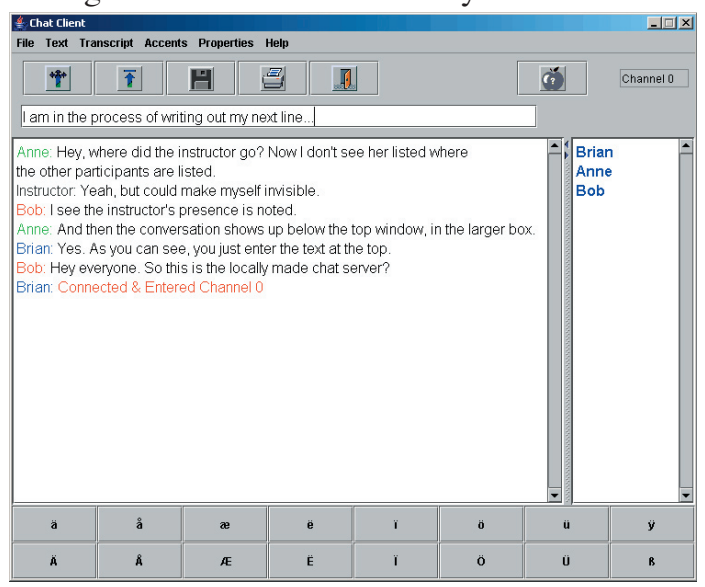

The chatter saw only the entries of the other participants in the specific chat room with the most recent entry appearing at the top of the discussion window. The teacher decided whether or not to be visible in the chat room. Although the teacher could observe only one chat room at a time, the full text of the discussion appeared on the teacher's screen upon entering the chat room.

\section{Second-semester Class}

The second semester class was a more traditional class of 20 students with most having limited experience in studying a FL. The students ( 7 females and 13 males) were between the ages of 18 and 24, except for one who was in his late 30s. These students chatted in pairs or groups of three for about 10-20 minutes at the end of class during their weekly lab hour. The chat activities were for the most part information-gap activities. The teacher used the IRC Français chat program (see Figure 2).

Figure 2

IRC Français Chat Program

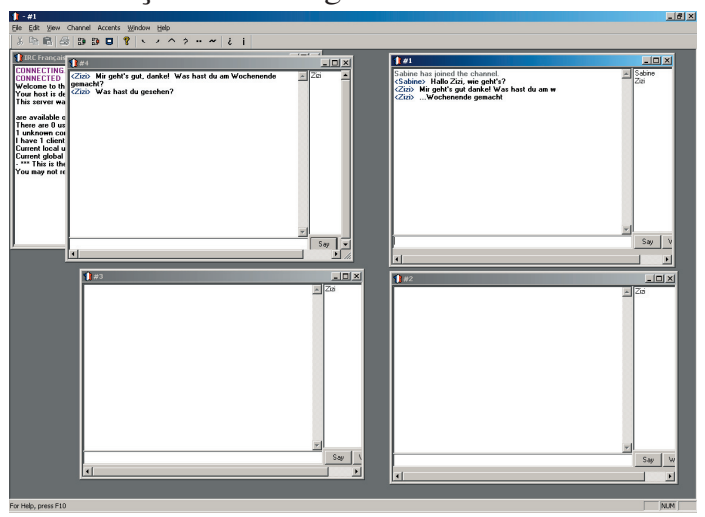


In contrast to the chat program developed by the College of Humanities at the University of Arizona, this program allows the teacher to be in four chat rooms at the same time, but the teacher is always visible to the students in those rooms.

\section{Chat Activities}

In both classes the chat tasks were either directly taken from the textbook Kontakte (Terrell, Tschirner, \& Nikolai, 2000) or slightly adapted to include a web quest. The two task types from Kontakte that the teachers considered appropriate for chat delivery were role-play and information-gap activities. The first-semester teacher used more role plays, whereas the second-semester teacher used more structured information-gap activities. While the specific tasks between the two classes differed, the nature of the tasks was comparable. Both task types were designed with the intention of creating meaningful discourse on a specified topic encouraging the use of the language structures of the chapter. An effort was made in both classes to relate the activities to the textbook as closely as possible because, as Müller-Hartmann (2000) and others have stressed, it is important to integrate CMC components directly into the regular classroom.

\section{DATA COLLECTION}

The data were collected using three instruments: chat transcripts, student surveys, and teacher interviews. Each is described in more detail below.

\section{Procedures}

For the purposes of this study, the students in the first-semester German section were randomly assigned chat partners in the first lab session during the second week of the semester. The students chatted once a week for 10-20 minutes for an entire semester. Pairs 1, 2, and 3 were always observed, while the other pairs were observed only on a few occasions. Due to a high fluctuation in attendance, the groupings were not as consistent as we would have liked, but they provided sufficiently consistent data for our purposes. In this class, the transcripts were corrected for grammatical mistakes and periodically returned to the students. However, most students reported to the teacher at the end of the semester that they did not consult the corrected transcript. The chat time was counted as $10 \%$ of the final grade; grades were assigned based on task completion and TL use, not on grammatical accuracy.

In the second-semester class, the teacher randomly assigned new chat partners for each lab session. The teacher observed four pairs at a time and rotated through the rooms so that she participated in all chat sessions for a short amount of time. Even though the second-semester students did not receive feedback on their chat transcript, the students still had the option of printing the transcripts for their own use. The students in this class were aware that the teacher would eventually read the transcripts to grade the assignments, which also counted as $10 \%$ of the final grade. This portion of the grade was also determined by task completion and TL use after the teacher reviewed the transcript. 


\section{Instruments}

\section{Transcripts}

The first four weeks of chat transcripts of the semester were excluded from the study to allow for a familiarization phase with the medium. Due to technical issues with the chat server, transcripts could not be retrieved for two additional chat sessions in each class. Hence, out of the 14 weeks of chatting during the semester, eight chat transcripts per class were collected and analyzed. Transcripts included posted messages and the screen names of the participants. Both chat programs automatically sort transcripts by person, which means that the transcripts for two partners can look quite different. For example, if Student 1 logs on before Student 2 , Student 2's transcript will not reflect any turns completed before his/her entry in the chat room; however, Student 1's will. Another commonality was that both programs automatically displayed messages indicating when another student entered or left the chat room. However, only the IRC program indicated the teacher entering and leaving the chat room. An additional difference is that the chat program developed by the University of Arizona indicated the time of posting. For sample transcripts, see Appendixes B and C.

\section{Student Survey}

The student survey was distributed to the participants after completion of all eight chat activities (see student survey in Appendix D). The survey was administered by one of the researchers not involved in the teaching of the class. The survey elicited students' perceptions about the usefulness of the chat activities and how they saw their own and others' roles in the chat sessions. Page 1 had Likert-type scale items with room for comments, and page 2 had open-ended questions.

\section{Teacher Interviews}

The two teachers who participated in the project were interviewed in order to elicit their perceptions about their participation style and influence on the chat room dynamics and the students' behavior during the chat sessions. Field notes were taken during the interview.

\section{DATA ANALYSIS}

\section{Transcripts}

Transcripts were coded for (a) teacher-student and student-student error correction, including explicit and implicit error correction realized as recasts; (b) uptake (correct and incorrect); (c) on- and off-task behavior; and (d) TL use. The totals in each category were computed and compared in the teacher-present and teachernot-present conditions.

In coding and reporting the findings below, a turn was operationalized as a posting in a chat session. When a participant in the chat hit enter to post his/her contribution to the chat, the posting was counted as a turn. This approach to defining turns was considered appropriate because the objective of the study was not to 
examine parts of speech or speech acts, which would have obligated the researchers to take into account various grammatical and discourse features as criteria for defining a turn. On a few occasions, code switching occurred within a posting. In these instances, the part in the TL was counted as a half turn. .5 in the tables below), and the part in the non-TL was counted as another half turn.

Spelling mistakes (such as typographical errors and capitalization) were counted as errors only when teacher or peer corrections ensued. The presence of a correction in this case signaled to the researchers that the spelling mistakes were perceived as errors that were serious enough from the point of view of the teacher or a peer to trigger corrective feedback. Among the types of error correction, we operationalized "modeling" as instances in which a chat participant (teacher or student) initiated the activity instead of the designated person. This often occurred after an exchange in which participants discussed what they were supposed to do. In example (1), the teacher models Sandra's ${ }^{1}$ part in the role play to help the student with her part of the task.

\section{Example 1}

Senta Ich bin Senta und ich komme aus Freiburg. [I'm Senta and I'm from Freiburg.]

Sandra Ich bin Sandra und ich komme aus Berlin. [I'm Sandra and I'm from Berlin.]

In our data sets, recasts tended to take the appearance of questions or statements in which an incorrect form was implicitly and correctly restated. Some recasts focused on the incorrect form, while others included the entire turn. Example (2) illustrates the use of a recast with a repetition of the phrase containing the most crucial mistake (wind), while ignoring the prepositional error (aus). The student turn immediately following the recast still contains an error, but the form at issue in the recast was corrected.

\section{Example 2}

Jon Es ist wind aus Berlin?

[Is it wind from Berlin?]

Senta es ist windig?

[is it windy?]

Jon Richtig... Es ist windig aus Berlin.

[Right ... It is windy from Berlin.]

When explicit corrections occurred, they were direct statements such as "No, that's not how you say ..." or "The way you say ... is ... ." In addition to formulations such as these, turns in the chat that followed an error and contained the corresponding correct form in a graphically enhanced manner (by putting the correct form between $<>$ or () ) were also tabulated as instances of explicit correction (see example [3]). Although recasts are generally considered implicit forms of feedback, in this study, in agreement with Nicholas et al. (2001), we considered a 
recast which was marked with $<>$ or ( ) as an explicit form of feedback because it was marked as a correction.

Example 3

Laura Wie heisst der Mann, der die "Mona Lisa" gemalt hat?

Kim Ich weiss nicht. Wem?

Zina (instructor) (Wer)

[I don't know. Whom?]

[(Who)]

Another type of error correction found in the transcripts consisted of metalinguistic statements of grammatical rules by the teacher. These were simply tabulated as rule explanation.

Modeling and recasts are types of implicit corrective feedback, and corrections such as the ones described in the paragraph above and rule explanation instances are types of explicit corrective feedback. In the findings section of the paper, results are summarized by keeping the four types of feedback separate in order to take into account that each type of corrective feedback may have had different effects on learner participation. However, in the discussion section the categories are collapsed into implicit and explicit corrective feedback.

When the students acknowledged a correction by repeating or reformulating their message using the corrected form (even if with slight deviations), the turn was counted as an instance of uptake (see example (2) above). Although Lyster and Ranta (2002) define uptake as student responses immediately following the feedback, we considered not only immediate but also delayed responses within the same chat session as uptake, as suggested by Mackey and Philp (1998). Correct usage in subsequent chats was not counted as uptake. Such usage could be seen as acquisition as a result of the feedback received; however, many other factors may have also contributed to the use of the correct form.

With respect to on- and off-task behavior, discussions in the TL or in English in which the chat participants were figuring out the topic of the task and their roles in it were counted as task-negotiation turns. The parts of the chat in which the participants discussed topics other than the one assigned were considered off task. In some of the role-play activities off-task behavior was harder to identify than in the information-gap activities. In the role plays, some exchanges could be considered as expanding on the task; however, if they encouraged further expansion which was clearly off task, then the turns that were part of the second expansion were considered off task, while the first expansion was considered on task. Example (4) illustrates this kind of situation in which the task was to plan a party. The students were asked to discuss what to prepare and bring to the party and to decide the time and location of the party. In the dialogue below, Mike initiates a discussion about who to bring, which is relevant but not part of the task. However, the second part of Kaiser's response sparks a long discussion about Napoleon and kings, which is no longer within the parameters of the task. (The off-task posts are in bold.) 
Example 4

Mike Kann ich Steffi Graf mitbringen?

[Can I bring Steffi Graf?]

Kaiser Ja, bring mitbring Steffi Graf, nicht ist Verwandte Napoleon. [Yes, bring with bring Steffi Graf, not is relative Napoleon.]

Mike Wer ist Napoleon, dein Freund?

[Who is Napoleon, your friend?]

Kaiser holen Sie kleine französische Konnigs ...

[Get small French kings...]

Kaiser bitte

[please]

Kaiser Corsicanisch

[Corsican]

Kaiser Napoleon kommt aus Corsica.

[Napoleon is from Corsica.]

Mike Franzosische Konnig ist nicht wie eine Deutsches Konnig, Ja?

[French king is not like a German king, yes?]

Kaiser Deutschland Deutschland uber alles..

[Germany Germany above everything..]

Mike Muss ich Wine bringen?

[Do I have to bring wine?]

\section{Student Surveys}

The quantitative results of the survey allowed for a numeric comparison of the two classes. Differences and similarities in the student surveys highlighted points of focus that could then be compared to the open-ended answers from the surveys and the results from the transcripts and teacher interviews.

\section{Teacher Interviews}

Teacher interview field notes were qualitatively analyzed and compared with the findings from the transcripts and student surveys. The underlying teaching philosophies were also extracted from the teacher interviews.

\section{SUMMARY OF RESULTS}

\section{Transcripts}

\section{First-semester German Class}

On/Off-task Behavior and TL Use

Whether the teacher was present or not, the students produced about the same number of turns (802 with the teacher present and 822 without the teacher present) (see Table 1). The actual time spent on chatting was also equal. In both conditions, the students were on task more than five times as often as they were off task ( $84 \%$ of the turns with the teacher present were on task; $83 \%$ without the teacher 
present). When the teacher was present, most of the off-task behavior was greetings (12\% of turns), which, when produced in the TL, were a welcome off-task behavior that the teacher considered a natural part of the conversation. When the teacher was not present, there was more off-task behavior of other sorts. On-task behavior involved more task negotiation when the teacher was not present. The differences in the two kinds of on-task behavior and two kinds of off-task behavior when the teacher was present in the chat room versus when the teacher was absent were significant, yielding a $\chi^{2}$ of $11.82(p<.01, d f=3)$.

Table 1

On- and Off-Task Behavior in the First-semester Class

\begin{tabular}{|c|c|c|c|c|c|c|c|}
\hline \multirow[t]{2}{*}{ Type of task } & \multicolumn{3}{|c|}{ Teacher present } & \multicolumn{3}{|c|}{ Teacher absent } & \multirow[t]{2}{*}{ Overall total } \\
\hline & $\begin{array}{l}\text { In target } \\
\text { language }\end{array}$ & $\begin{array}{c}\text { Not in } \\
\text { target } \\
\text { language }\end{array}$ & Total & $\begin{array}{l}\text { In target } \\
\text { language }\end{array}$ & $\begin{array}{c}\text { Not in } \\
\text { target } \\
\text { language }\end{array}$ & Total & \\
\hline Doing task & 566 & 33 & 599 & 532 & 70 & 602 & 1,201 \\
\hline Negotiating task & 38 & 34 & 72 & 51 & 33 & 84 & 156 \\
\hline On-task total & 604 & 67 & 671 & 583 & 103 & 686 & 1,357 \\
\hline $\begin{array}{l}\text { Greetings (off } \\
\text { task) }\end{array}$ & 90 & 6 & 96 & 56 & 17 & 73 & 169 \\
\hline $\begin{array}{l}\text { Other off-task } \\
\text { behavior }\end{array}$ & 35 & 0 & 35 & 59 & 4 & 63 & 98 \\
\hline Off-task total & 125 & 6 & 131 & 115 & 21 & 136 & 267 \\
\hline Overall total & 729 & 73 & 802 & 698 & 124 & 822 & 1,624 \\
\hline
\end{tabular}

Non-TL use constituted $15 \%$ of turns in the teacher-not-present condition, and only $9 \%$ of turns in the teacher-present condition. A $2 \times 2$ table comparing TL and non-TL use when the teacher was present versus when she was absent yields a $\chi^{2}$ of $13.08(p<.001, d f=1)$, demonstrating a strong relationship between TL use and the teacher's presence. However, non-TL use was low under both conditions.

\section{Corrective Feedback}

In the first semester class, corrective feedback by the teacher was mostly implicit and all except for once in the TL. Modeling (9 occurrences) and recasts (22 occurrences) made up $94 \%$ of the corrective feedback (see Table 2).

Table 2

Teacher-to-student Error Correction in the First-semester Class

\begin{tabular}{lccc}
\hline \hline Type of error correction & In target language & Not in target language & Total \\
\hline Modeling & 9 & 0 & 9 \\
Recasting & 22 & 0 & 22 \\
Correction & 1 & 0 & 1 \\
Rule explanation & 0 & 1 & 1 \\
Total & 33 & 1 & 34 \\
\hline
\end{tabular}


The 34 instances of corrective feedback resulted in only one correction uptake by a student. There was one instance of correction uptake following peer correction and nine instances of error uptake, with or without the teacher present (see Table 3).

Table 3

Students' Uptake of Corrections and Errors in the First-semester Class

\begin{tabular}{lccc}
\hline \hline Type of uptake & Teacher present & Teacher absent & Total \\
\hline Uptake following teacher correction & 1 & 0 & 1 \\
Uptake following peer correction & 1 & 0 & 1 \\
Error uptake & 5 & 4 & 9 \\
\hline
\end{tabular}

Although the teacher remained the main source of corrective feedback, students engaged with the teacher as a communication partner rather than a source for correction. The students seemed to view the teacher's postings as focusing more on conveying meaning and moving the discussion forward than on providing error correction.

When the teacher was present, she provided 34 error corrections to students, but students (peer-to-peer) provided only six error corrections, totaling 40 error corrections in all during the teacher's presence. Another seven tokens of peer-topeer error correction occurred in the teacher's absence. There were five instances of students' error uptake when the teacher was present and four when the teacher was absent (see Table 3).

Table 4

Peer-to-peer Error Correction and Self-correction in the First-semester Class

\begin{tabular}{lccc}
\hline \hline Type of error correction & Teacher present & Teacher absent & Total \\
\hline Modeling & 1 & 1 & 2 \\
Recasting & 5 & 6 & 11 \\
Total peer correction & 6 & 7 & 13 \\
Self-correction & 3 & 1 & 4 \\
\hline
\end{tabular}

The frequency of implicit error correction used by students increased as the semester progressed. Self-correction occurred three times with the teacher present and only once without the teacher present.

\section{Second-semester German Class}

On/Off-task Behavior and TL Use

The second semester students spent most of their turns on task, both when the teacher was present $(76 \%)$ and when the teacher was not present in their chat room $(71 \%)$, and greetings constituted a large portion of off-task behavior (see Table 5). There were only 8 tokens of task negotiation when the teacher was present, compared to 66 when the teacher was absent. 
Table 5

On- and Off-Task Behavior in the Second-semester Class

\begin{tabular}{|c|c|c|c|c|c|c|c|}
\hline \multirow[t]{2}{*}{ Type of task } & \multicolumn{3}{|c|}{ Teacher present } & \multicolumn{3}{|c|}{ Teacher absent } & \multirow[t]{2}{*}{ Overall total } \\
\hline & $\begin{array}{l}\text { In target } \\
\text { language }\end{array}$ & $\begin{array}{c}\text { Not in } \\
\text { target } \\
\text { language }\end{array}$ & Total & $\begin{array}{l}\text { In target } \\
\text { language }\end{array}$ & $\begin{array}{c}\text { Not in } \\
\text { target } \\
\text { language }\end{array}$ & Total & \\
\hline Doing task & 398 & 0 & 398 & 612 & 0 & 612 & 1,010 \\
\hline Negotiating task & 5 & 3 & 8 & 45 & 21 & 66 & 74 \\
\hline On-task total & 403 & 3 & 406 & 657 & 21 & 678 & 1,084 \\
\hline $\begin{array}{l}\text { Greetings (off } \\
\text { task) }\end{array}$ & 75 & 1 & 76 & 152.2 & 8.5 & 161 & 237 \\
\hline $\begin{array}{l}\text { Other off-task } \\
\text { behavior }\end{array}$ & 51 & 1 & 52 & 118 & 1 & 119 & 171 \\
\hline Off-task total & 126 & 2 & 128 & 270.5 & 9.5 & 280 & 408 \\
\hline Overall total & 529 & 5 & 534 & 927.5 & 30.5 & 958 & 1,492 \\
\hline
\end{tabular}

The students remained in the TL to an overwhelming extent in both conditions (99\% with the teacher and $97 \%$ without the teacher), although the difference was still significant $\left(\chi^{2}=6.53, p<.05, d f=1\right)$. Overall, the students produced almost twice as many turns when the teacher was not in the chat room. A 2 X4 table of teacher presence and teacher absence against the two kinds of on-task behavior and two kinds of off-task behavior yields a $\chi^{2}$ of $29.42(p<.00001, d f=3)$, indicating a strong relationship between the teacher's presence and the kinds of turns produced by the students.

\section{Corrective Feedback}

In the second semester course, most of the teacher-to-student corrective feedback consisted of explicit and immediate corrections (48\%) (See Table 6). The teacher made these corrections in the TL by retyping misspelled words or grammatically incorrect formulations, often times between arrows $(<>)$ or parentheses. She used unmarked recasts much less frequently (14\%).

Table 6

Teacher-to-student Error Correction in the Second-semester Class

\begin{tabular}{lccc}
\hline \hline Type of error correction & In target language & Not in target language & Total \\
\hline Modeling & 13 & 1 & 14 \\
Recasting & 6 & 0 & 6 \\
Correction & 21 & 0 & 21 \\
Rule explanation & 1 & 2 & 3 \\
Total & 41 & 3 & 44 \\
\hline
\end{tabular}

The second most preferred type of corrective feedback consisted of modeling instances $(32 \%)$, also in the TL. In these instances, the teacher was the one who initiated the conversation on the assigned topic upon noticing that the students in a 
chat group were confused about what their task was (as evidenced by the students asking each other, in English, what they were supposed to do). The total of 44 corrections given by this instructor resulted in 20 instances of uptake by the targeted student (45\% of total corrections made by the teacher) (see Table 7). There were also two instances of correction uptake and seven instances of error uptake, with or without the teacher in both cases.

Table 7

Students' Uptake of Corrections and Errors in the Second-semester Class

\begin{tabular}{lccc}
\hline \hline Type of uptake & Teacher present & Teacher absent & Total \\
\hline Uptake following teacher correction & 20 & 0 & 20 \\
Uptake following peer correction & 1 & 1 & 2 \\
Error uptake & 2 & 5 & 7 \\
\hline
\end{tabular}

The teacher's presence in or absence from the chat room did not seem to affect the second semester students' use of corrective feedback with their peers or themselves (see Table 8). There were four instances of peer-to-peer corrective feedback when the teacher was not in the chat room and two when the teacher was present. Self-corrections were just as frequent in both conditions (four occurrences in each condition) as were correction uptakes (one occurrence in each condition).

Table 8

Peer-to-peer Error Correction and Self-correction in the Second-semester Class

\begin{tabular}{lccc}
\hline \hline Type of error correction & Teacher present & Teacher absent & Total \\
\hline Modeling & 1 & 0 & 1 \\
Recasting & 1 & 4 & 5 \\
Total peer correction & 2 & 4 & 6 \\
Self-correction & 4 & 4 & 8 \\
\hline
\end{tabular}

\section{Survey}

A survey was given to the students during a class period following the completion of the chat activities analyzed in this study (see student survey in Appendix D). Each question had four choices to keep the students from defaulting to neutral answers. The responses were coded on a scale of one to four, with four indicating the most positive response. Averages were computed and $t$ tests were run to check for significant differences. Ten of the 14 students in the first-semester class completed the survey; 18 of the 20 students in the second-semester class completed it. Although not all the students in the two classes completed the surveys, all students' transcripts were nevertheless analyzed since the survey was intended to provide insight into the students' perceptions. Furthermore, due to the anonymous nature of the survey, it was impossible to identify the students who did not complete it. Therefore, the surveys included in the analysis here have to 
be treated with some caution because not all of the chat participants' perceptions are reflected in the results.

Overall, a similarly high and positive response came from students in both classes. Reported use of the TL (Item 1) was the same in both classes, with a mean of 3.7 and a mode of 4 (see Table 9).

Table 9

First- and Second-semester Class Survey Results

\begin{tabular}{|c|c|c|c|c|c|}
\hline \multirow[t]{2}{*}{ Item } & & \multicolumn{2}{|c|}{$\begin{array}{l}\text { First semester } \\
(\mathrm{n}=10)\end{array}$} & \multicolumn{2}{|c|}{$\begin{array}{l}\text { Second semester } \\
(\mathrm{n}=18)\end{array}$} \\
\hline & & Mean & Mode & Mean & Mode \\
\hline & My chat partner and I interacted in German. & 3.7 & 4 & 3.7 & 4 \\
\hline & Chatting was frustrating.* & 2.7 & 2 & 3.0 & 3 \\
\hline & $\begin{array}{l}\text { I asked my partner for clarification through chat } \\
\text { instead of doing it face-to-face. }\end{array}$ & 2.9 & 3 & 3.6 & 4 \\
\hline 4. & I received useful corrections from others. & 2.8 & 2 & 2.5 & 3 \\
\hline & $\begin{array}{l}\text { I was able to correct my own mistakes while } \\
\text { chatting. }\end{array}$ & 3.0 & 3 & 2.8 & 3 \\
\hline 6. & $\begin{array}{l}\text { The teacher's presence made me feel self- } \\
\text { conscious.* }\end{array}$ & 3.5 & 4 & 2.8 & 2 \\
\hline 7. & $\begin{array}{l}\text { The chat conversations went at the right speed for } \\
\text { me. }\end{array}$ & 3.3 & 3 & 3.0 & 3 \\
\hline 8. & I found the chat activities to be a waste of time.* & 3.3 & 3 & 3.7 & 4 \\
\hline 9. & I worked well with my partner. & 3.5 & 3 & 3.6 & 4 \\
\hline 10. & The teacher's presence made me feel secure. & 2.7 & 2 & 2.8 & 3 \\
\hline & $\begin{array}{l}\text { I found chat activities to be beneficial for my } \\
\text { learning of German. }\end{array}$ & 3.0 & 4 & 3.0 & 3 \\
\hline 12. & $\begin{array}{l}\text { Printed transcripts were helpful to have after the } \\
\text { chat. }\end{array}$ & 2.7 & 3 & 1.3 & 1 \\
\hline & $\begin{array}{l}\text { There was a connection between chat activities and } \\
\text { classroom activities. }\end{array}$ & 3.0 & 3 & 3.3 & 4 \\
\hline \multirow[t]{2}{*}{14.} & My chat partner and I stayed on task. & 3.4 & 3 & 3.2 & 3 \\
\hline & Overall mean & 3.1 & & 3.0 & \\
\hline
\end{tabular}

$1=$ never, 2 = rarely, $3=$ often, 4 = very often

*Negative items $(2,6$, and 8$)$ reverse coded so that higher numbers indicate more positive attitudes.

Item 9 asked about how well the students worked with their partner. The means were 3.5 (mode 3 ) and 3.6 (mode 4 ) in the first-semester class and second-semester class, respectively. Responses to Item 14 about staying on task were also nearly equal in the classes, mean of 3.4 (mode 3 ) in the first-semester class and mean of 3.2 (mode 3 ) in the second-semester class. The same mean of 3.0 was found for both classes in response to Item 11, which dealt with how beneficial the chat activities seemed to the students. The students also reported similar experiences in being able to correct themselves (Item 5), with means of 3 and 2.8 in the 
classes. It should be noted, however, that in the space where students could make additional comments, quite a few students in both classes specified that they were only able to catch and correct their spelling mistakes, which were not considered in the analysis of the transcripts.

To investigate differences in the students' perceptions between the first- and second-semester classes, their responses to the questionnaire items were submitted to $t$ tests. Analysis showed significant differences for only two items. For item 3 , in which the students indicated how much of their interaction was done exclusively through the computer chat, the mean for the second-semester class was significantly higher than that of the first-semester class. In fact, several students in the first-semester class reported having spoken face to face to their partners for clarification purposes. The mean for item 12, which asked about the usefulness of the printed transcripts, was significantly higher for the first-semester class than for the second-semester class. This result may be attributed to the fact that printed transcripts were never corrected by the teacher in the second-semester class but were regularly marked by the teacher in the first semester class.

Two items spoke directly to the teachers' roles in the class: items 6 and 10 . These items were meant to be nearly equivalent, but students' responses diverged considerably. Item 10 asked students whether the teacher's presence made them feel secure. Some students commented that they tried to ignore their teacher's presence unless they had a question. Two students in the first-semester class remarked that they had not noticed their teacher's presence. Not surprisingly, these students were in pairs that the teacher was not able to visit during chat sessions due to the experimental design of the project. One student in second-semester German commented that she felt a little nervous in the teacher's presence. Comments about feeling nervous were much more common with item 6 , which asked about self-consciousness in connection with the teacher's presence. Two students in the first-semester class who wrote a comment about this item said that the teacher helped them keep on task. In the second-semester class, some students, none of whom selected an extreme response of one or four, commented that they did not feel intimidated by the teacher. Other students, however, wrote specifically that they felt nervous during chat activities because, as one student put it, the teacher was there "waiting for me to make a mistake."

The open-ended questions on the survey asked about the teacher's involvement and what pros and cons the students saw in the activities. Students in the first-semester class spoke positively about their teacher's role by speaking of her "handsoff approach," her ability to maintain order, and her "insightful" comments and by noting that the chat activities encouraged "self-thinking." All but one of the students said something about how the activities promoted personal interaction. A few students commented positively on their teacher's occasional grammar correction, and no one complained that there was too little correction.

The second-semester students painted a clear picture of their teacher's constant involvement and frequent and clearly marked error correction. All students commented on the teacher's involvement, but their reactions were divided. More than half of the students praised their teacher for being so involved and active in their 
chat sessions. Several commented that error correction was exactly what they needed, wanted, and got from the activities. One even went so far as to lament that some errors remained uncorrected. Another student commented that chat was like a more relaxed form of talking. Four students out of 18, however, wrote about feeling nervous because of their teacher's involvement. These students felt that the teacher corrected them too much and that her corrections interrupted their conversations.

\section{Interviews}

The first-semester teacher, one of the researchers in the project, was interviewed about her motivations and goals with chat by one of the other researchers. The teacher's comments indicated that much of her inspiration for using chat is that it is a novel activity that adds variety to class. It is also an alternative forum for conversation. For this teacher, conversational flow is of the highest importance during chat and other communicative activities in the classroom. She strives to get her students to work largely independently, as opposed to relying on her as the teacher to keep an activity going, and she prefers not to correct students' errors while they are concentrating on how to express meaning. As she said, "If my grandmother could understand it, then I don't have to correct it." By this she means that she limits her correction during chat to errors that cause breakdowns in communication, or, occasionally, errors that others in the class can understand but that are too far from the TL as to pass the "grandma" test.

This teacher does not believe, however, that there is no place for error correction. On the contrary, she believes that the opportunity to later correct printed chat transcripts in a detailed fashion is one of the primary benefits of using chat in a FL classroom. By correcting the transcript later, as opposed to correcting the output at the time of its utterance, the teacher can attend to details without interrupting the original flow of conversation. Nevertheless, review of her students' transcripts showed that more than half of her responses address the content of what students say rather than their grammar or spelling.

The teacher of the second-semester class characterized herself as a "chat zealot" and chose authority figures such as "mentor," "expert," "mother," "police," "older sister," and "dictionary" to define her role as a language teacher. She identified two main purposes that motivate her to use chat: one-communicative in nature - is to trigger learner output by assigning a discussion topic; the other is to create opportunities to practice recently taught linguistic forms (which she referred to as the "form of the day"). In her opinion, learners participating in a chat session tend to see the activity as fun but fail to concentrate on linguistic forms the way she, as a teacher, would like them to. This teacher also said she uses chat to make corrections that she cannot make in spoken interaction, such as spelling and capitalization. She indicated that she engages in more corrections in chat "because they [the students] can see." She claims she has different ways of responding to various kinds of errors: she corrects capitalization, spelling, and agreement errors; suggests new word forms or phrases for vocabulary; asks clarification questions 
to correct grammar; avoids recasting because the speed of the chat does not allow it; and calls the chat participants back to task in role-play activities by asking a question from the suggested questions list.

Another criterion that guides this teacher's corrective behavior in the chat room is her perception of the students involved in the interaction. Thus, "perfectionists" receive corrective feedback on more than the "form of the day," while the weaker students do not. She does not use the chat printouts to give corrective feedback; instead, she assigns a grade based on the participants' consistent use of the TL and completion of the task at hand.

\section{DISCUSSION}

In this study, effects of the teachers' presence and participation style were analyzed by examining differences in TL use, on- and off-task behavior, and error correction. These are discussed in more detail below.

\section{TLUse}

In both classes, non-TL use was lower when the teacher was present than when she was not: $9 \%$ versus $15 \%$ in the first-semester class and $1 \%$ versus $3 \%$ in the second-semester class, and, in both classes, the differences were statistically significant. Although these percentages may intuitively seem lower than they would be for face-to-face communication, this result corroborates and refines findings of other studies. For example, Ortega (1997) stated that "There is also anecdotal evidence that backsliding into the L1 is minimized in electronic discussion (Beauvois, 1992; Chun, 1994; Kelm, 1992; but see Kern, 1995)" (p. 87). It is also possible that since the students have more time to formulate and can erase errors before sending the message (and even access online dictionaries), actual turns on screen can be more easily posted in the TL (see also Ortega, 1997).

In the absence of pressure to pronounce the TL (Warschauer, 1998), students might be more willing to experiment with the FL, and this willingness may, in turn, also explain the high percentage of German used by the students. One student on the survey, in explaining why she reported chatting as never being frustrating, declared, "No way! Way less frustrating than stumbling on spoken words." Knowing that transcripts can be looked at by the teacher, as well as seeing one's own writing, may increase levels of accountability and hence offer another explanation for the limited use of English.

The second-semester class completed all of the activities in the TL and only resorted to non-TL use in task negotiation and off-task turns. Since the secondsemester activities included more information gap activities, which were more tightly structured with leading questions and partial answers already provided, it was easier for the students to stay on task and use the TL. Role-play activities, which were more frequently used in the first-semester class, allowed for greater on-task non-TL use. Non-TL use in both classes was more frequent when off task than when on task. In the final analysis, taking all the factors above into account, the presence of the teacher had a clear impact on students' use of the TL in the chat sessions in this study. 


\section{On-/Off-task Behavior}

The students in the first-semester class were on task $84 \%$ of the turns in comparison to $73 \%$ of the turns of the students in the second-semester class. The less structured activities allowed the first-semester students to express themselves or socialize within the limits of the task, while personal expression in the secondsemester class was likely to be off task. Most of the off-task turns in both classes under both conditions were greetings, and the variation was not significantly different $\left(\chi^{2}=1.62, p=.20, d f=1\right)$. In the survey at the end of the project, students also reported staying on task almost all of the time, which is supported by the teachers' impressions and the analysis of the transcripts.

Interestingly, on- and off-task behavior was almost the same in both conditions in the first-semester class: $84 \%$ on task with the teacher present and $83 \%$ without the teacher present, the difference being insignificant $\left(\chi^{2}=0.002, p=.96, d f=1\right)$. However, in the second-semester class students stayed on task better when the teacher was present $(76 \%)$ in comparison to when she was not $(71 \%)$, and this difference was significant $\left(\chi^{2}=4.51, p<.05, d f=1\right)$.

\section{Error Correction}

Error correction by peers and self-correction, with or without the teacher present in either class, was very infrequent. Error uptake was comparable under both conditions in the first-semester class and more frequent without the teacher present in the second-semester class. Since the students in second semester showed a higher tendency to engage in uptake processes in general, they may have been more trained to be more sensitive to differences between their language production and that of another person. When the teacher was not present and, therefore, not able to correct mistakes, error uptake was a distinct possibility. In the context of the high number of total turns produced by the students in the TL in both classes and under both conditions, error uptake was low. The number of correction uptakes was lower than the number of error uptakes in the first-semester class. However, not all errors were corrected, and the number of errors far exceeded the number of corrections. Analysis also revealed that some apparent error uptake, especially in the first-semester class (where students relied on third personal singular verb forms found in the model task instead of conjugating the verbs to first or second person), may have been interlanguage errors that the students were producing because they were at the same developmental stage. These realizations should weaken worries about error uptake expressed by others (Beauvois, 1992; Kelm, 1992; Storch, 2002). However, the issue deserves more attention in future research.

The corrective feedback style of the two teachers differed. In both cases the form of feedback directly reflects the teachers' teaching philosophy. The firstsemester teacher mainly used implicit forms of error correction (94\%), while the second-semester teacher predominantly employed explicit forms of error correction $(55 \%)$. The explicit error correction style resulted in much more student uptake. In the first-semester class, only $3 \%$ of the teacher's corrections resulted in student uptake, but, in the second-semester class, $45 \%$ of the corrections resulted 
in uptake. One interpretation of this dramatic difference might be that explicit error correction is a more effective means of correction. Alternatively, it may reflect the fact that implicit error correction does not require acknowledgment of the correction, as has been suggested by Lyster and Ranta (1997). Since recasts integrate the corrective feedback into the natural flow of conversation, a restatement of the incorrect phrase may seem unnatural or even an interruption of the conversational flow. Explicit error correction, on the other hand, is in itself already an interruption of the conversation and may suggest to the students that it requires proof of understanding the correction. As a result, a visible and immediate response to the correction may be more likely with explicit feedback, which may or may not reflect an actual effect on SLA. Furthermore, not all uptake will actually lead to an integration of the form into the learner's TL grammar. To complicate things further, some error correction that is not followed by uptake may ultimately lead to a change in the interlanguage grammar.

The students' responses in the survey indicated that they tended to embrace the corrective feedback style employed by their particular teacher. Although no negative comments were made about the participation style of the first-semester teacher, there were several negative comments made by the students about the second-semester teacher. For the most part, students responded positively to both teachers, but some students in second semester reported feeling nervous and selfconscious in the teacher's virtual presence. The negative comments were usually embedded with positive feedback, for example "It's helpful to have someone correct mistakes, but on the other hand, it makes me a little nervous." This might explain why the second-semester students produced fewer turns in the teacher's presence. The fact that the second-semester students produced almost twice as many turns when the teacher was not present in their chat rooms suggests that this teacher's participation style may have a silencing effect on the students. In contrast, the numbers of turns produced by the students in first semester were nearly equal in the two conditions (49\% with the teacher present and 51\% with the teacher absent). When relating these numbers to comments made in the student surveys, it appears that the silencing effect was due to the teacher's participation style, not simply to her presence. This finding also supports other studies' suggestions that learners participating in a conversation may perceive too much teacher participation as stifling (Lynch, 1997) and that limited teacher intervention in ongoing conversations may be desirable (Walsh, 2002). In a somewhat different CMC context, Donaldson and Kötter (1999) found that FL learners who were communicating with a native speaker of the TL perceived the teacher's help as an intrusion.

\section{CONCLUSIONS}

The original purpose of this investigation was to determine the importance of teachers' participation in a chat. As illustrated above, not only did teachers' participation turn out to be important, but even more so, the teacher's participation styles proved to influence learners' participation in chat. The conclusions with respect to the study's research questions are detailed below. 
The study revealed different teacher interaction styles based on sharply different philosophies about the teacher's role in chat. The first-semester teacher defined herself as primarily a communication partner, avoided interrupting the natural flow of conversation, and gave implicit corrective feedback. In the chat transcripts, most of this teacher's turns were content related. On the other hand, the second-semester teacher viewed herself as an authority figure and took it upon herself to enforce rules. Student perceptions supported her self-identified role of police and expert, which also emerged in the transcripts.

In terms of the effects of a teacher's presence on learners' interaction, the study revealed that the teacher's presence in or absence from the chat room correlated with systematic differences in student behavior only in terms of turns produced, as will be explained below. Peer-to-peer error correction, self-correction, correction uptake, and error uptake were limited in both classes and in both conditions.

The teacher's presence or absence did not correlate with dramatic differences in on- or off-task behavior. In the first-semester class, the differences were not significant, and in the second-semester class the differences were significant but only moderate. By taking into account the types of on- and off-task behavior (including task negotiation and greetings versus other behaviors), we found greater shifts in behavior depending on whether the teacher was present or absent. Under both conditions, non-TL use was very low, although significantly more non-TL turns were produced in the teachers' absence.

The most notable differences between the teacher-present and teacher-absent conditions was the total number of turns produced by the students. In the secondsemester class the students produced almost twice as many turns when the teacher was not in the chat room. This dramatic difference was not observed in the firstsemester class. When total turns produced with the teacher present and the teacher absent are compared between the two classes, the difference is significant and strong $\left(\chi^{2}=58.11, p<.00001, d f=1\right)$. Hence, the identified silencing effect can be attributed not to the teacher's presence in the chat room but rather to the teacher's participation style. In this situation, the more form-oriented teacher of the secondsemester class seemed to cause some performance anxiety in the learners.

The students' perceptions about the teacher's role in and effect on chat room interactions were overall positive and matched both the teachers' self-descriptions in the interviews and the findings based on the transcript analysis. In general, the students appreciated receiving input and corrective feedback from their teachers in that particular teacher's style. However, some second-semester students remarked that their teacher's presence and participation styles made them feel self-conscious.

\section{IMPLICATIONS AND RECOMMENDATIONS}

Generalizations cannot be made on the basis of this study due to certain limitations such as the small number of participants, differences in class profiles, and differences in chat software and implementation. Future adaptations of this study should attempt to control the abovementioned variables. A further interesting investigation would be to analyze the roles of the teacher when chatting from re- 
mote locations without a physically close presence.

Generally, it was clear that students enjoyed chatting and saw it as a valuable part of the language classroom. For example, one student in the first-semester class expressed the following opinion: "The advantages [of chatting] would be practicing and self-thinking sharpens ones [sic] responses when involved in a dialogue. Rather than just absorbing. The disadvantage, well I cant [sic] think of any right now." Similarly, a student in the second semester wrote: "Advantages: helps to improve one's ability to communicate, switches things up a bit. Disadvantages: NONE!" Remarks such as these support recommendations that chat be used in beginning-level FL classes such as the ones included in this study.

From a pedagogical standpoint, this study suggests that language teachers involved in chats with their beginning-level students might want to adopt a conversational style in order to stimulate student participation and output production, a beneficial factor in SLA (Swain, 1985). At this level, corrective feedback seems to be least inhibiting when implicit. The effectiveness of one corrective feedback style versus another needs further investigation with better measurements of effectiveness than uptake. Once such a measurement can be identified, other issues can be analyzed. One intriguing question that remains is how the visual modality in chat alters the nature of error correction.

\section{NOTE}

${ }^{1}$ The names of all participants in the study other than those of the researchers are pseudonyms.

\section{REFERENCES}

Batson, T. (1988). The ENFI project: A networked classroom approach to writing instruction. Academic Computing, 2, 32-33.

Beauvois, M. H. (1992). Computer-assisted classroom discussion in the foreign language classroom: Conversation in slow motion. Foreign Language Annals, 25, 455464.

Beauvois, M. H. (1997). High-tech, high-touch: From discussion to composition in the networked classroom. Computer Assisted Language Learning, 10 (1), 57-69.

Beauvois, M. H. (1998a). Conversation in slow motion: Computer-mediated communication in the foreign language classroom. Canadian Modern Language Review, 54 (2), 198-217.

Beauvois, M. H. (1998b). Write to speak: The effects of electronic communication on the oral achievement of fourth semester French students. In J. A. Muyskens (Ed.), New ways of learning and teaching: Focus on technology and foreign language education (pp. 93-115). Boston: Heinle \& Heinle.

Böhlke, O. (2003). A comparison of student participation levels by group size and language stages during chatroom and face-to-face discussions in German. CALICO Journal, 21 (1), 67-87. 
Bump, J. (1990). Radical changes in class discussion using networked computers. Computer and the Humanities, 24, 49-65.

Carroll, S., \& Swain, M. (1993). Explicit and implicit negative feedback: An empirical study of the learning of linguistic generalizations. Studies in Second Language Acquisition, 15, 357-386.

Chun, D. (1994). Using computer networking to facilitate the acquisition of interactive competence. System, 22 (1), 17-31.

Donaldson, R. P., \& Kötter, M. (1999). Language learning in Cyperspace: Teleporting the classroom into the target culture. CALICO Journal, 16 (4), 531-557.

Gass, S. M., \& Selinker, L. (2001). Second language acquisition. An introductory course. Mahwah, NJ: Lawrence Erlbaum.

Gonzalez-Bueno, M. (1998). The effects of electronic mail on Spanish L2 discourse. Language Learning and Technology, 1 (2). 55-70. Retrieved May 9, 2005, from http://lit.msu.edu/vol1num2/article3/default.html

Izumi, S., Bigelow, M., Fujiwara, M., \& Fearnow, S. (1999). Testing the output hypothesis. Effects of output on noticing and second language acquisition. Studies in Second Language Acquisition, 21, 421-452.

Kelm, O. R. (1992). The use of synchronous computer networks in second language instruction: A preliminary report. Foreign Language Annals, 25, 441-454.

Kern, R. (1995). Restructuring classroom interaction with networked computers: Effects on quantity and characteristics of language production. Modern Language Journal, 79 (4), 457-476.

Kern, R. (1998). Technology, social interaction, and FL literacy. In J. A. Muyskens (Ed.), New ways of learning and teaching: Focus on technology and foreign language education (pp. 57-92). Boston: Heinle \& Heinle.

Kost, C. R. (2004). An investigation of the effects of synchronous computer-mediated communication (CMC) on interlanguage development in beginning learners of German: Accuracy, proficiency, and communication strategies. Unpublished doctoral dissertation, University of Arizona, Tucson.

Kötter, M. (2003). Negotiation of meaning and codeswitching in online tandems. Language Learning and Technology, 7 (2), 145-172. Retrieved May 9, 2005, from http://1lt.msu.edu/vol7num2/kotter/default.html

Long, M. H. (1996). The role of the linguistic environment in second language acquisition. In W. C. Ritchie \& T. K. Bhatia (Eds.), Handbook of second language acquisition (pp. 413-468). New York: Academic Press.

Long, M. H., \& Robinson, P. (1998). Focus on form: Theory, research, and practice. In C. Doughty \& J. Williams (Eds.), Focus on form in classroom second language acquisition (pp. 15-41). Cambridge, UK: Cambridge University Press.

Lynch, T. (1997). Nudge, nudge: Teacher interventions in task-based learner talk. ELT Journal, 51, 317-325.

Lyster, R. (1998). Negotiation of form, recast, and explicit correction in relation to error types and learner repair in immersion classrooms. Language Learning, 48 (2), 183-218. 
Lyster, R., \& Ranta, L. (1997). Corrective feedback and learner uptake: Negotiation of form in communicative classrooms. Studies in Second Language Acquisition, 19, 37-66.

Mackey, A., \& Philp, J. (1998). Conversational interaction and second language development: Recasts, responses, and red herrings? Modern Language Journal, 82 (2), 338-356.

Müller-Hartmann, A. (2000). The role of tasks in promoting intercultural learning in electronic learning networks. Language Learning and Technology, 4 (2), 129-147. Retrieved May 9, 2005, from http://llt.msu.edu/vol4num2/muller/default.html

Nicholas, H., Lightbown, P. M., \& Spada, N. (2001). Recasts as feedback to language learners. Language Learning, 51 (4), 719-758.

Oliver, R. (1995). Negative feedback in child NS-NNS conversations. Studies in Second Language Acquisition, 17, 459-481.

Oliver, R. (2000). Age differences in negotiation and feedback in classroom pair work. Language Learning, 50, 119-151.

Ortega, L. (1997). Processes and outcomes in networked classroom interaction: Defining the research agenda for L2 computer-assisted classroom discussion. Language Learning and Technology, 1 (1), 82-93. Retrieved May 9, 2005, from http://llt. msu.edu/vol1num1/ortega/default.html

Panova, I., \& Lyster, R. (2002). Patterns of corrective feedback and uptake in an adult ESL classroom. TESOL Quarterly, 36 (4), 573-595.

Payne, J. S., \& Whitney, P. J. (2002). Developing L2 oral proficiency through synchronous CMC: Output, working memory, and interlanguage development. CALICO Journal, 20 (1), 7-32.

Saxton, M. (1997). The contrast theory of negative input. Journal of Child Language, 24, 139-161.

Storch, N. (2002). Patterns of interaction in ESL pair work. Language Learning, 52, 119158.

Swain, M. (1985). Communicative competence: Some roles of comprehensible input and comprehensible output in its development. In S. M. Gass \& C. G. Madden (Eds.), Input in second language acquisition (pp. 235-53). Rowley, MA: Newbury House.

Swain, M., \& Lapkin, S. (1995). Problems in output and the cognitive processes they generate: A step towards second language learning. Applied Linguistics, 16 (3), 371 391.

Terrell, T., Tschirner, E., \& Nikolai, B. (2000). Kontakte: A communicative approach. New York: McGraw Hill.

Walsh, S. (2002). Construction or obstruction: Teacher talk and learner involvement in the EFL classroom. Language Teaching Research, 6, 3-23.

Warschauer, M. (1996). Comparing face-to-face and electronic discussion in the second language classroom. CALICO Journal, 13, 7-25.

Warschauer, M. (1998). Interaction, negotiation, and computer-mediated learning. Retrieved October 23, 2002, from http://www.insa-lyon.fr/Departements/CDRL/interaction.html 


\section{APPENDIX A}

Sample Activity

Familie

Stellen Sie sich vor, Sie haben ein Jahr als Austauschstudent/in in Deutschland bei einer Familie gewohnt, um besser Deutsch zu lernen. Nach einem Jahr gehen Sie in die USA zurück und treffen einen Freund/ eine Freundin, der/die auch gerade ein Jahr in Deutschland war. Sie erzählen sich gegenseitig von Ihren Familien.

1. Gehen Sie zu der Webseite und lernen Sie über die Familie:

Partner 1: http://home.rhein-zeitung.de/ uherkenr/d-index.htm

Partner 2: http://rotacker.de

2. Erzählen Sie Ihrem Partner/ Ihrer Partnerin von Ihrem Leben in Deutschland.

Stellen Sie Fragen und beantworten Sie Fragen:

- In welcher Stadt wohnt die Familie?

- Wie heißen die Mutter, der Vater und die Kinder?

- Wie alt sind sie?

- Was machen die Eltern gern? Was machen die Kinder in ihrer Freizeit?

- Wie sehen die Eltern und die Kinder aus?

- Wann machen die Kinder was?

\section{APPENDIX B}

Transcript from the first-semester class

$\mathrm{S} 1=$ Student $1 \quad \mathrm{~S} 2=$ Student $2 \quad \mathrm{~T} 1=$ Teacher 1

Channel 1 on 09/24/03

S1 (20:25:11): Connected \& Entered Channel 1

S1 (20:25:17): Hallo S2!

S2 (20:25:24): hallo S1!

S2 (20:26:10): Ich will take "page 57"

S1 (20:26:52): Ich don't know what that meansw

S1 (20:26:56): *means

S1(20:27:15): por supuesto!

S1(20:27:51): Was macht Mehmet am Montag?

S2(20:28:30): Ergeht um 7 Uhr...

S2(20:28:40): zur Arbeit

S2(20:28:50): Was macht Silvia am Montag?

S1 (20:29:4): ein minuten bitte

S1 (20:29:43): Silvia, am Montag, steht um 6 Uhr auf.

S1 (20:30:25): okay, was macht Silvia am Dienstag?

S2 (20:31:8): Sie arbeit am Abend in eine Kneipe

S1 (20:31:43): toll

S2 (20:32:2): Was machtst du am Montag?

S1 (20:32:38): Ich gehe in die Universität

S1 (20:33:13): Was machst DU am Montag? 
S2 (20:34:57): Ich geht un 8 Uhr zur Arbeit un Ich habe Deutsche un 19 Uhr

S1 (20:35:30): Toll!

S2 (20:35:51): S1, was macht Mehmet Sengün on Dienstag?

S1 (20:36:16): Mehmet lernt eine neue Kollegin kennen am Dienstag.

S1 (20:37:46): Und was macht Mehmet am Mittwoch?

S2 (20:38:40): Er singt im Mannerchor

S2 (20:38:53): Und was macht Mehmet am Freitag?

S1 (20:40:23): Er hört um 15 Uhr mit der Arbeit auf.

S2 (20:42:31): qhe???

$\mathrm{T}$ (20:43:02): So, dann macht jetzt bitte die zweite Aufgabe.

S2 (20:44:15): Meine familie haben ein Sohn, Er heißt Adrian

S2 (20:45:8): Adrians bester Freund heiße Raphael

S2 (20:46:20): Wer ist im dein familie?

S1 (20:46:45): toll! Meine familie habt ein Sohn und zwei Töchter

S1 (20:47:44): Der Vater kocht gern, aber Kochen ist nicht dein Beruf.

S1 (20:48:45): Und die Mutter ist sehr schön!

T1 (20:49:6): So, so, ...... ;-)

S2 (20:49:9): Der Vater in meine familia auch Kochen gern!

S1 (20:49:24): Enchuldigung!

S1 (20:49:45): Bis bald S2 und T1!

\section{APPENDIX C}

Transcript from the second-semester class

S3 $=$ Student $3 \quad$ S4 $=$ Student $4 \quad$ T2 $=$ Teacher 2

Nickname: S3

10/08/2003 (Wednesday) 17:41:23

S4 has joined the channel.

$<$ S4 $>$ Gutentag!

$<$ S3 $>$ howdy

$<$ S3 $>$ uh

$<$ S4 $>$ Wischt du oft den Tisch ab?

$<$ S3 $>$ nein, Ich habe nie den Tish abgewischt

$<$ S3 $>$ hast du heute morgan dein bett machen?

$<$ S3 $>$ Bett*

$<$ S3 $>$ er, gemacht

$<$ S4 $>$ nein, Ich habe nicht Bett gemachen

$<$ S3 $>$ Must du bald wieder dein Klo putzen?

$<$ S4 $>$ whats klo?

T2 has joined the channel.

$<$ S3 $>$ das Klo $=$ die Toilette 


\section{APPENDIX D}

\section{Survey}

All questions refer to your perceptions of your German class chat sessions. Please indicate how often the following statements could be applied to your chat experiences and then provide an explanation or further commentary below. Your honest feedback is appreciated. You are welcome to write more at the end of the survey if there is not enough room for your comments.

Your name (optional)

\begin{tabular}{|c|c|c|c|c|}
\hline & Never & Rarely & Often & $\begin{array}{l}\begin{array}{l}\text { Very } \\
\text { often }\end{array}\end{array}$ \\
\hline \multicolumn{5}{|l|}{ 1. My chat partner and I interacted in German. } \\
\hline \multicolumn{5}{|l|}{ Explain: } \\
\hline \multicolumn{5}{|l|}{ 2. Chatting was frustrating. } \\
\hline \multicolumn{5}{|l|}{ Explain: } \\
\hline \multicolumn{5}{|l|}{$\begin{array}{l}\text { 3. I asked my partner for clarification through chat } \\
\text { instead of doing it face-to-face. }\end{array}$} \\
\hline \multicolumn{5}{|l|}{ Explain: } \\
\hline \multicolumn{5}{|l|}{ 4. I received useful corrections from others. } \\
\hline \multicolumn{5}{|l|}{ Explain: } \\
\hline \multicolumn{5}{|l|}{$\begin{array}{l}\text { 5. I was able to correct my own mistakes while } \\
\text { chatting. }\end{array}$} \\
\hline \multicolumn{5}{|l|}{ Explain: } \\
\hline \multicolumn{5}{|l|}{$\begin{array}{l}\text { 6. The teacher's presence made me feel self- } \\
\text { conscious. }\end{array}$} \\
\hline \multicolumn{5}{|l|}{ Explain: } \\
\hline \multicolumn{5}{|l|}{$\begin{array}{l}\text { 7. The chat conversations went at the right speed } \\
\text { for me. }\end{array}$} \\
\hline \multicolumn{5}{|l|}{ Explain: } \\
\hline \multicolumn{5}{|l|}{ 8. I found the chat activities to be a waste of time. } \\
\hline \multicolumn{5}{|l|}{ Explain: } \\
\hline \multicolumn{5}{|l|}{ 9. I worked well with my partner. } \\
\hline \multicolumn{5}{|l|}{ Explain: } \\
\hline \multicolumn{5}{|l|}{ 10. The teacher's presence made me feel secure. } \\
\hline \multicolumn{5}{|l|}{ Explain: } \\
\hline \multicolumn{5}{|l|}{$\begin{array}{l}\text { 11. I found chat activities to be beneficial for my } \\
\text { learning of German. }\end{array}$} \\
\hline Explain: & & & & \\
\hline
\end{tabular}




\begin{tabular}{|l|l|l|l|l|}
\hline $\begin{array}{l}\text { 12. Printed transcripts were helpful to have after the } \\
\text { chat. }\end{array}$ & & & & \\
\hline Explain: & & & & \\
\hline $\begin{array}{l}\text { 13. There was a connection between chat activities } \\
\text { and classroom activities. }\end{array}$ & & & & \\
\hline Explain: & & & & \\
\hline 14. My chat partner and I stayed on task. & & & & \\
\hline Explain: & & & & \\
\hline
\end{tabular}

Open-ended questions:

1. Which chat activity did you enjoy the most? Why?

2. How does this chat experience compare to other experiences in German class?

3. How did you feel about your teacher's involvement in these activities?

4. In your view, what are the advantages and disadvantages to using chat in a language class?

Thanks for your input! 


\title{
ACKNOWLEDGMENTS
}

The authors (listed alphabetically) wish to thank the two anonymous CALICO reviewers for their insightful comments and suggestions, as well as Dr. Renate Schulz for her feedback on an earlier version of the paper. Our appreciation also goes to James Hudson and Amy Bruckman at Georgia Technological Institute, who designed and gave us permission to use the chat program IRC Français, as well as to the College of Humanities at the University of Arizona for their chat program. Lastly, our sincere thanks to the participants, students, and teacher in the study.

\section{AUTHORS' BIODATA}

Estela Ene is a Ph.D. Candidate in the Interdisciplinary Program in Second Language Acquisition and Teaching at the University of Arizona, majoring in pedagogy and minoring in linguistic analysis. She teaches English composition, Italian, and linguistics, and she served as editor of the Student's Guide to First-Year Composition. Her research interests include advanced ESL writing, CMC, and issues of international GTAs.

Senta E. Görtler is a Ph.D. Candidate in the Second Language Acquisition and Teaching Program at the University of Arizona with a major in pedagogy and a minor in German Studies. At the University of Arizona, she teaches all levels of German and the language-specific portion of the Teaching Methods course and also serves as the Assistant to the Director of Basic Languages. In addition, she teaches ESL at Pima Community College and works for the ESL software developer of English, Baby Inc. Her research interest is in CMC, particularly the role of the teacher during chat.

Kara McBride is a Ph.D. Candidate in the interdisciplinary Second Language Acquisition and Teaching Program at the University of Arizona, majoring in pedagogy and minoring in psycholinguistics. Her recent studies have focused on information literacy and the use of computer chat in the foreign language classroom. She teaches ESL and Spanish and was the primary designer of the CALL research website CODI (http://coh.arizona.edu/codi). She is interested in what insights psycholinguistics can give to teaching and assessment practices and how that might be applied to educational software and web page design.

\section{AUTHORS' ADDRESSES}

\author{
Estela Ene \\ Department of English \\ University of Arizona, Tucson \\ 1423 E. University Boulevard, Room 445 \\ Tucson, AZ 85721 \\ Phone: 520/621-1836 \\ Fax: $\quad 520 / 621-7397$ \\ Email: enes@u.arizona.edu
}


Senta E. Görtler

German Studies Department

University of Arizona, Tucson

1512 E. 1 st Street

Tucson, AZ 85721

Phone: 520/621-7385

Fax: $\quad 520 / 626-8268$

Email: sentag@u.arizona.edu

Kara McBride

SLAT Program

Transitional Office Building

1731 E. Second Street, Room 211

P.O. Box 210014

Tucson, AZ 85721

Phone: 520/235-8569

Fax: $\quad 520 / 626-3230$

Email: kmcbride@u.arizona.edu 